\title{
Insularity And Imperial Politics: Hadrian On The Greek Islands
}

\author{
Anna Kouremenos ${ }^{1}$
}

\section{ABSTRACT}

Since its conquest by Rome in the 2 nd century BCE, Roman notables were a constant presence in Greece. While various sites on the mainland served as battlegrounds for Roman civil wars during the 1st century BCE (e.g., Pharsalus, Actium, Philippi), the early imperial period was characterized by the use of various Greek islands as places of - often self-imposed exile and/or isolation for such notables as M. Vipsanius Agrippa (Lesbos) and Tiberius (Rhodes). Other imperial Romans sojourned in the Aegean islands for different reasons. Augustus spent a winter on Samos after his victory at Actium, using it as a temporary powerbase for the refinement of his imperial plans, and he visited it and other islands again as emperor. While the first two Julio-Claudian emperors maintained close contacts with the Greek world, in the 2nd century CE Hadrian took this connection a step further and promoted Hellenism as a major part of his imperial policy. Naturally, the Greek islands played an important role in imperial politics during his reign, but only as components of the wider Hellenic world and not as isolated entities. Hadrian visited Rhodes and Paros to restore and venerate older Hellenic monuments - the Colossus and the tomb of the poet Archilochus respectively - and possibly Samothrace in order to be initiated into the Mysteries of the Great Gods. He also visited other islands in Greece, but his exact travel itinerary can only be speculative given our fragmentary literary and epigraphic evidence. In this paper, I focus on Hadrian's presence on the Aegean islands and argue that during his reign they served mainly as sites that allowed for the implementation of his imperial plans by virtue of their easy access from the mainland Greek and Asian provinces. Accordingly, by promoting

\footnotetext{
${ }^{1}$ DPhil in Archaeology at the University of Oxford; Lecturer in Ancient History at Quinnipiac University, USA. Email: akouremenos@qu.ed.
} 
Mare Nostrum, ano 2021, v. 12, n. 2

certain aspects of older Hellenic culture on specific islands, Hadrian conferred renewed prestige to these islands in the Roman Empire.

\section{KEYWORDS}

Roman Greece, Hadrian, insularity, Roman imperialism, Aegean islands. 


\section{Introduction}

Long before the Roman conquest of mainland Greece in the 2nd century BCE, individuals from Italy were a constant presence on the Greek mainland and islands, initially as merchants and traders and later as students and settlers. Once all of Greece was incorporated into the Roman Empire by $67 \mathrm{BCE},{ }^{2}$ various sites on the mainland (e.g., Pharsalus, Actium, Philippi) served as battlegrounds for Roman civil wars during much of the second half of the 1st century BCE. In contrast, the period of the so-called Pax Romana (27 BCE-180 CE) saw a marked interest in the usage of various Greek islands as places of self-imposed exile, with such notables as Agrippa (Lesbos) and Tiberius (Rhodes) being the best-known Roman exiles on the islands of the Aegean. Other imperial personages sojourned on the Greek islands for different reasons, Augustus wintering on Aegina and Samos on two separate occasions, and Hadrian visiting Rhodes, Paros, and other islands to restore monuments and venerate the ancient Greek past. It is not an exaggeration to claim that, for many elite Romans, Greece came to be seen as a "Plan B" in case the situation in Rome and Italy became unbearable and/or inhospitable for them. That Greek islands served various purposes for elite Romans is therefore not unusual since they were located at the cross-roads between east and west. Added to their appeal was the fact that imperial Romans and their elite circles were generally familiar with Hellenic culture and language, making the Greek islands attractive dwellings as opposed to insular communities closer to Rome. Curiously, given their proximity to the Italian mainland, the Ionian islands do not feature prominently in the lives of imperial Romans who visited and remained in Greece for some time. ${ }^{3}$ Our available sources suggest that emperors were almost exclusively interested in the Aegean and Cycladic islands and generally overlooked the insular landscapes of the Ionian Sea. The reasons for the latter's marginalization are not clearly understood, but what is evident is that the Aegean world held much more appeal for certain emperors.

With the exception of Crete, none of the Greek islands had Roman colonies, ${ }^{4}$ but many harbored resident populations from Italy. Some small Cycladic and Aegean islands

\footnotetext{
${ }^{2}$ Crete was the last territory within the borders of modern Greece to be incorporated into the Roman Empire between 69-67 BCE. On this topic, see especially papers in Francis and Kouremenos 2016 with bibliography.

${ }^{3}$ The Roman period on the Ionian islands is, in general, poorly understood and researched. For a general overview of the evidence, see most recently Zoumbaki 2018 with bibliography.

${ }^{4}$ The sole Roman colony on Crete was Colonia Iulia Nobilis Cnossus on the site of the earlier Greek city of Knossos.
} 
had long served as places of exile, ${ }^{5}$ with a few gaining the reputation for being some of the most inhospitable places in the Roman Empire. Gyaros is a prominent example, with ancient sources preserving allusions to its destitute environment; so desolate was this small Cycladic island that one ancient author claims that on Gyaros even the rats ate rust! ${ }^{6}$ Other, more hospitable, Greek islands sometimes functioned as places of exile for powerful individuals who had fallen out of favor with emperors and their inner circles. A case in point is the twice-exiled orator T. Cassius Severus, who, after authoring a series of defamatory pamphlets against Augustus' new imperial order, was exiled to Crete. ${ }^{7}$ This must have been a rather comforting location for an involuntary exile since the island is not only the largest in Greece but also contained a number of prosperous cities and a thriving economy during the Pax Romana. Apparently Severus maintained the antiimperial rhetoric on the island, and some years later his polemics reached the emperor Tiberius, who finally exiled him - and subsequently banned his writings - to the much less hospitable Cycladic island of Serifos. ${ }^{8}$ Augustus' right-hand man, M. Vipsanius Agrippa, spent considerable time on the island of Lesbos on self-imposed exile, allegedly so that he might not seem to oppose or belittle the political career of Marcellus, Augustus' nephew, by his presence in Rome. ${ }^{9}$ In the 2nd century CE, the sophist Favorinus of Arelate in Gaul, who had risen to prominence as a pre-eminent intellectual in the Greek world despite being a barbarian, was banished to Chios after falling out of favor with his patron, Hadrian. ${ }^{10}$ It is evident that being exiled in his case did not mean being cut off from the world. Chios, so close to the mainland of the province Asia, where Smyrna and Ephesus were two of the most important centers of literary and cultural activity during the 2 nd century $\mathrm{CE}$, may have been chosen precisely for this reason: the island was quiet enough to serve its purpose as a place of exile yet near enough to the important centers on the Anatolian mainland that a quick boat trip would have made it easily accessible. Several other examples of prominent elite individuals who were voluntarily or involuntarily exiled to Greek islands could be cited, ${ }^{11}$ but as this paper deals specifically

\footnotetext{
${ }^{5}$ Le Quéré 2018; Sweetman 2016.

${ }^{6}$ Ael., NA, 5.15.

${ }^{7}$ On the career and exile of T. Cassius Severus in general, see Braginton 1944; D'Hautcourt 1995; Rudich 2006; Evans 2015. It is not known where in Crete he chose to settle.

${ }^{8}$ See Sweetman 2016 with bibliography.

${ }^{9}$ Suet., Tib. 10.1.

${ }^{10}$ Cass. Dio, 69.4.1-5; Collart 1932; Swain 1989. See also Bowie 1997 for a different interpretation.

${ }^{11}$ See especially Sweetman 2016 for a recent treatment of Roman exiles in the Cyclades. 
with Hadrian and his role in defining insularity in the Greek world, this is not the place to discuss non-imperial individuals further.

In what follows, I focus on Hadrian's presence on the Greek islands and the theme of insular connectivity versus isolation during his reign (117-138 CE). Although our evidence for the emperor's presence on various Greek islands is incomplete, enough literary and epigraphic testimonies survive to elicit some conclusions about the roles that certain islands played in his imperial policies. Unlike the evidence for the first two JulioClaudian emperors, the literary testimonies for Hadrian's reign are rather poor, and we must rely heavily on the epigraphic record which is itself very fragmentary. Below I discuss what our available ancient sources permit us to conclude about the emperor's presence on certain Greek islands, the imperial precedents that may have guided his journeys and political motives, and the place of the Greek islands within the wider Hadrianic policy of consolidation and Hellenocentrism.

\section{Imperial precedents}

Hadrian was not the first Roman emperor to spend considerable time on the Greek islands. During his war with Marc Antony and Cleopatra's forces in the Battle of Actium in $31 \mathrm{BCE}$, Augustus briefly encamped on the Ionian island of Cephallenia while his rival Antony made the neighboring island of Zakynthos one of his bases in western Greece. ${ }^{12}$ After his victory at Actium, Augustus may have visited Leucas briefly since a large number of its inhabitants were later relocated to his newly established city of Nicopolis in Epirus. ${ }^{13}$ No other emperor during the Pax Romana is recorded to have visited the Ionian islands, although a possible visit by Hadrian, even if not documented in our surviving sources, is plausible given his many trips to and from Greece during his lifetime. ${ }^{14}$

Augustus (r. 27 BCE-14 CE) visited Greece twice after his victory at Actium in 31 $\mathrm{BCE}$, and he seems to have preferred sojourning on islands rather than the mainland. Three of these islands - Samos, Aegina, and Rhodes - were generally amicable to Rome, and it was in them that he chose to remain for some time during his imperial visits to the

\footnotetext{
${ }^{12}$ See Zoumbaki 2018, 55-56 with bibliography.

${ }^{13}$ Anth. Pal., 2.13. On the population that formed Nicopolis, see especially Kirsten 1987; Purcell 1987; Isager 2001.

${ }^{14}$ On Hadrian's travels in general, see Dürr 1881; Birley 1997; more recently, see D’Ambrosi 2020 with bibliography.
} 
Greek East. In the case of Samos, he received ambassadors from India on his second trip there in 21/20 BC. ${ }^{15}$ Due to its strategic location and alliance with Rome, Augustus made Samos the base for his war with Parthia. Later, he met Herod of Judea on Rhodes, where the latter pledged allegiance to him even though he had originally supported Marc Antony. ${ }^{16}$ Although it was not unusual for a travelling emperor to meet dignitaries outside Rome, the choice of the two Aegean islands to conduct political meetings set a precedent for Hadrian, who was an admirer of Augustus and followed many of his policies. ${ }^{17}$

No imperial Roman is as connected to a Greek island as Augustus' successor, Tiberius (r. 14-37 CE). Much has been written about the motive(s) that drove this emperor suddenly to go on a six-year, self-imposed exile on Rhodes before assuming the imperial throne, and these are as obscure today as they were to our surviving ancient sources. The reasons provided range from the indiscretions of his wife Julia, to holding a grudge against Augustus for favoring his own grandchildren for the imperial throne, to his desire for recreation and furthering his education, among others. ${ }^{18}$ Whatever the real motive for Tiberius' sudden departure from Rome - and it is likely to have been a combination of reasons - for the purposes of this paper, I shall turn briefly to the evidence for the future emperor's withdrawal to the island. Two questions are pertinent for the overall theme of this dossier: why did he choose Rhodes for his self-imposed exile, and what did he do on the island for six years?

Tiberius' relationship with Rhodes predated his voluntary exile there. Evidently, he chose to withdraw to the island because of its beauty and healthfulness, ${ }^{19}$ and lived there as a semper privatus, a civilian without offices. Suetonius reports that he partook in activities associated with elite Greek males: attending lectures and debates by renowned philosophers and orators, frequenting the gymnasium, involving himself in philanthropic deeds, and wearing Greek clothes. ${ }^{20}$ Added to these was his interest in astrology; it was on Rhodes where he fell under the influence of Thrasyllus, a renowned Alexandrian astrologer whose descendants - G. Julius Antiochus Philopappos and Julia Balbilla -

\footnotetext{
${ }^{15}$ Cass. Dio, 54.9.8. See also Schmalz 1997.

${ }^{16}$ Joseph., $A J, 15.6 .6$.

${ }^{17}$ On Augustus as a role-model for Hadrian, see especially Birley 1997; Spawforth 2011; Seebacher 2020 with bibliography.

${ }^{18}$ Four extant ancient sources provide theories for Tiberius' sudden exile to Rhodes: Velleius Paterculus, Tacitus, Suetonius, and Cassius Dio. For commentary, see especially Levick 1972; Seager 1972, 29-35; Bellemore 2007.

${ }^{19}$ Suet., Tib., 11.1.

${ }^{20}$ Bellemore 2007, 425. 
would have close connections to Hadrian and the imperial family in the 2 nd century CE. ${ }^{21}$ Suetonius records that Tiberius owned two modest houses on the island, one in the town of Rhodes and another, a villa suburbana, in an unspecified location. ${ }^{22}$ At some point during his exile, Tiberius pleaded with Augustus to return to the imperial capital, but the request was refused. ${ }^{23} \mathrm{~A}$ few years before he was eventually allowed to return to Rome, Tiberius visited Gaius, Augustus' grandson and presumed heir-apparent, on Samos. ${ }^{24}$ It appears that after this meeting, Tiberius decided to spend most of his time until his return to Rome in $2 \mathrm{CE}$ in seclusion on Rhodes, avoiding contact with ships carrying highranking officials who flocked to the island to meet him. It is tempting to speculate that some of Tiberius' later depravity on the island of Capri may have had its roots during his years on Rhodes, but the extant ancient sources do not provide any salacious details to corroborate this view. In any case, the long sojourn on Rhodes augmented Tiberius' philhellenism, and he later even pleaded with Augustus and the senate on behalf of Greek communities. ${ }^{25}$ After he became emperor in $14 \mathrm{CE}$, he did not visit Rhodes or any other Greek island again.

Following Tiberius' reign, no Roman emperor visited Greece until Nero (r. 54-68 CE). ${ }^{26}$ The latter's notorious tour of Achaea, where he competed in the major games and contests and remained for a year, culminated in his proclamation of the freedom of the province. There is no evidence that he visited any islands during his year-long tour, and he also famously avoided visiting Athens and Sparta. One of his short-reigning successors, Galba (r. 68-69 CE), claimed maternal descent from the mythic Cretan queen Pasiphae, ${ }^{27}$ but did not set foot on Crete while he was in power. After Nero, no other emperor visited Greece while on the imperial throne until Trajan (r. 98-117 CE), ${ }^{28}$ and it was not until the reign of his successor, Hadrian, that the Greek islanders would receive imperial visits and attention to the revival of their ancient past.

\footnotetext{
${ }^{21}$ See especially Birley 1997; Brennan 1998; Kouremenos forthcoming.

${ }^{22}$ Suet., Tib., 11.

${ }^{23}$ Suet., Tib., 13.

${ }^{24}$ Suet., Tib., 12.

${ }^{25}$ Suet., Tib., 8. See also Rutledge 2008 with bibliography.

${ }^{26}$ On Tiberius' relationship with the Greek world in general, including his early visits, see Rutledge 2008.

${ }^{27}$ Suet., Galb., 2. See also Morgan 2006, 31-32.

${ }^{28}$ Cass. Dio, 68.17.2. Trajan stopped in Athens on his way to Parthia and was met in the city by an embassy from king Osroes, who asked him for peace and proffered gifts. It is unclear how long the emperor remained in Athens.
} 


\section{Restoring the insular past? Hadrian and the Aegean world}

Hadrian's close relationship with the Greek world predated his imperial visits to Greece and has been the subject of considerable scholarship in the past century. ${ }^{29} \mathrm{He}$ was, as far as is known, the only Roman emperor to have become a citizen and eponymous archon of Athens before ascending the imperial throne in $117 \mathrm{CE}{ }^{30}$ Thus, he was a regular on the Greek scene already as a private citizen and did much to foster Hellenism in the Empire during his reign. Here is not the place to discuss the various ways he promoted the Greek past in the Roman Empire. The rest of this paper examines his promotion of two aspects that relate to the theme of insularity: his restoration program that was closely tied to the promotion of the Hellenic past, and - closely related to this his cultural and religious predilections, which were not limited to islands but nonetheless helped revive the prestige and economy of some insular communities in Greece.

Unlike two of his predecessors, Augustus and Tiberius, Hadrian's relationship with the Greek world was centered, above all, around the old centers of the province of Achaea - Athens, Delphi, and Sparta, among other cities. ${ }^{31}$ He held offices in all three poleis, including that of eponymous archon in Athens, ${ }^{32}$ archon at Delphi, ${ }^{33}$ and patronomos in Sparta, ${ }^{34}$ albeit the latter two were held in absentia. These and other offices in Greek cities reveal his close relationship with the Greek world, but also the reverence and support of his Hellenic subjects. Nevertheless, unlike Augustus and Tiberius, he did not single out any of the islands for long sojourns and seems to have had a marked preference for the cities on the mainland, especially Athens. The only Greek islands for which there is firm evidence for his presence are Rhodes and Paros, but surely the absence of literary and epigraphic evidence for other islands reflects our fragmented literary, epigraphic, and archaeological record. Although attempts to reconstruct the emperor's exact route in the Aegean are speculative, it is, in any case, certain that he visited several islands since a passage in the Historia Augusta states that "he sailed from Asia by way of the islands to

\footnotetext{
${ }^{29}$ For a list of relevant bibliographic sources on Hadrian and the Greek world, see most recently LagogianniGeorgakarakos and Papi 2018; Kouremenos forthcoming.

${ }^{30}$ Before Hadrian, Domitian was eponymous archon of Athens as emperor in 85-86 CE, but in absentia. On Hadrian's presence in and relationship with Athens before his ascension to the imperial throne, see Kouremenos forthcoming.

${ }^{31}$ On this aspect, see especially papers in Kouremenos 2022.

${ }^{32}$ IG II 1764 and 1832. He held this office in 112-113 and possibly also in 124-125. For the latter, see Kapetanopoulos 1992-1998, 217-218; Kouremenos forthcoming.

${ }^{33} \mathrm{He}$ held this office at least twice; $S y l l^{3}, 830,836$.

${ }^{34}$ See especially Bradford 1986; Kennell 2022.
} 
Achaea". ${ }^{35}$ This route is also confirmed by a treatise on physiognomy written by his friend, M. Antonius Polemo of Laodicea, who accompanied the emperor on at least some of his travels in Greece and Asia Minor. ${ }^{36}$

Let us first consider the evidence for Hadrian's presence on Rhodes since the sources are clear that he visited the island. Epigraphic documents from Ephesus preserve sections of the emperor's letters regarding Erastus and Philocyrius, sea-captains who took him by boat from that city to Rhodes. ${ }^{37}$ It is not at all surprising that the emperor chose this large island for a sojourn, even if the exact length of his stay there is unknown, as is the location of his habitation. While on this island, he may have inspected the house in which Tiberius had lived for six years. ${ }^{38}$ Well before Tiberius' lifetime, Rhodes had attracted many illustrious Roman students, including Cicero, Caesar, and Marc Antony, and by Hadrian's reign it had been an ally of Rome for several centuries. ${ }^{39}$ The large Aegean island was not only famous for its schools of rhetoric and philosophy but also for being the only island in Greece to have contained one of the seven wonders of the ancient world, the Colossus, which originally stood on its main harbor. By the 2nd century, however, the statue lay in ruins for over four centuries, having been toppled by an earthquake in 226 BCE. Moreover, people from all over the Empire still flocked to see the statue in its ruined state. Pliny the Elder, writing in the second half of the 1st century $\mathrm{CE}$, describes the remains of the Colossus in his own day: ${ }^{40}$

fifty-six years after it was erected, it was thrown down by an earthquake; but even as it lies, it excites our wonder and admiration. Few men can clasp the thumb in their arms, and its fingers are larger than most statues. Where the limbs are broken

\footnotetext{
${ }^{35} \mathrm{HA}, \mathrm{Hadr}$., 13.1.

${ }^{36}$ On Polemo's treatise, which survives in Latin and Arabic translations as well as in a Greek epitome, see Gleason 1994, 30; Swain and Bladel 2008 with bibliography.

${ }^{37} S_{I} G^{3}$ 838. Hadrian employed Erastus - and presumably also Philocyrius - on more than one occasion; see Halfmann 1986; van Nijf and Meijer 1992, 72; Birley 1997, 172.

${ }^{38}$ Birley 1997, 173.

${ }^{39}$ On the relationship between Rhodes and Rome, see especially Gruen 1975; Ager 1991; Erskine 1991; on rhetoric and philosophy on Rhodes, see Enos 2004 with bibliography.

${ }^{40}$ Plin., HN, 34.18. Translated by J. Bostock and H.T. Riley.
} 
asunder, vast caverns are seen yawning in the interior. Within it, too, are to be seen large masses of rock, by the weight of which the artist steadied it while erecting it.

For an emperor with pronounced antiquarian tastes and a predilection for restoring antique monuments, the remains of one of the ancient wonders would have presented a rare opportunity. In many parts of the Greek world, Hadrian ordered the restoration of older structures that lay in ruins, often incorporating them into new structures; some of the better-documented of these restorations/renovations in Greece include the Temple of Olympian Zeus in Athens, ${ }^{41}$ the Temple of Poseidon Hippios in Mantinea, ${ }^{42}$ and the Temple of Apollo in Abae, ${ }^{43}$ among many others. It is in this spirit of restoration, then, that the ruins of the Colossus must have piqued his interest.

John Malalas' Chronographia, written in the 6th century, notes that:

in his reign, Hadrian re-erected the Colossus of Rhodes, which had fallen during an earthquake Rhodes suffered in earlier times, and lay on the ground for 312 years, with nothing having been lost. He spent to restore and erect it in the same place, for machines and ropes and artisans, 3 hundredweight, as he inscribed the year and expenses below it. ${ }^{44}$

This passage has been dismissed as fictional by some scholars mainly due to problems with the given year of the restoration, ${ }^{45}$ with one scholar claiming that Malalas' assertion is "complete balderdash". ${ }^{46}$ Apart from the fact that 312 years after 226 BCE do not add up to the reign of Hadrian, ${ }^{47}$ another objection to the authenticity of Malalas' statement is that historical sources between his reign and the lifetime of the author would

\footnotetext{
${ }^{41}$ Cass. Dio, 69.6.1; HA, Hadr., 13.6.

42 Paus., 8.10.2.

${ }^{43}$ Paus., 10.35.3-4. On the extent of Hadrian's restoration, see especially Yorke 1896; Birley 1997; Grigoropoulos 2015.

${ }^{44}$ Malalas, Chronographia, 11.18. Translated by B. Kiesling.

45312 years from $226 \mathrm{BCE}$ add up to $86 \mathrm{CE}$, which would mean the reign of Domitian (r. 81-96). Boatwright 2000, 24f34 dismisses Malalas' claim of the restoration of the Colossus during Hadrian's reign, while Birley 1997, 173 does not take a firm stand on the issue.

${ }^{46}$ Boatwright 2000, 24.

${ }^{47}$ Malalas seems to have miscalculated the year, or else the number is due to a scribal error. 
have alluded to the restoration of such a grand monument, and it is true that no such references survive until the latter wrote about it in the 6th century. Neither do Rhodian coins from Hadrian's reign onward hint at a re-erected Colossus, ${ }^{48}$ although a full-length depiction of the statue is not known to have been represented on Rhodian coins during its heyday in the 3rd century BCE. Moreover, it must be noted that the biographies of Hadrian have come down to us mainly as epitomes, and they are generally not much concerned with the emperor's restorations, some of which are known strictly from epigraphic sources. In any case, Malalas must have relied on an earlier source or sources for his assertion as it is unlikely that he simply fabricated the information about the reerection of the Colossus in Hadrian's reign.

Pausanias, writing a generation after Hadrian, mentions some of the emperor's restorations, and as his Periegesis is concerned specifically with the province of Achaea, he does not refer to Hadrian's other restorations elsewhere in Greece and the islands. Surely, re-erecting the Colossus would have been a major undertaking, and I argue that Pausanias seems to hint that such an endeavor occurred in the earlier part of the 2nd century CE. In a passage where he describes the colossal statue inside the Temple of Olympian Zeus in Athens, which was inaugurated in c. 131/132 CE, he notes:

Before the entrance to the sanctuary of Olympian Zeus - Hadrian the Roman emperor dedicated the temple and the statue, one worth seeing, which in size exceeds all other statues save the colossi at Rhodes and Rome. ${ }^{49}$

Pausanias' choice of words in this passage

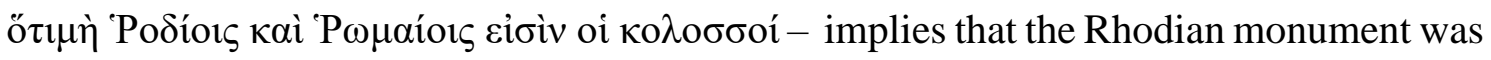
standing in his own lifetime in the mid-2nd century. Thus, he provides some indirect confirmation for Malalas' statement that Hadrian had indeed restored it. There is some additional literary evidence that hints at a restored and re-erected Colossus, albeit this

\footnotetext{
${ }^{48}$ On the coins of Rhodes, see especially Maryon 1956; Ashton 1988 and 2001; De Callatay 2006; Kebrick 2019 with bibliography.

${ }^{49}$ Paus. 1.18.6. Translated by W.H.S. Jones.
} 
derives from much later sources postdating the 6th century. Theophanes the Confessor, writing less than two centuries after Malalas, describes an Arab raid on Rhodes:

In this year Mauius came to Rhodes and demolished the Colossus of Rhodes 1360 years after it had been built. A Jewish merchant of Edessa bought it and loaded 900 camels with its bronze. ${ }^{50}$

This reference makes it clear that the statue did not lay in ruins on the ground but had to be demolished so that its bronze could be carried off. Versions of this story proliferated in various later texts in Greek and Syriac, ${ }^{51}$ and the supposed inscription on the statue's base is given in Constantine VII Porphyrogenetus' De Administrando Imperio: ${ }^{52}$

The Rhodian Colossus, eight times tencubits in height, Laches of Lindos

made.

Taken together, the passages from Pausanias, Malalas, and later writers offer some support for the restoration and re-erection of the Colossus at an earlier date, most likely in the reign of Hadrian, although additional restorations after his reign must not be ruled out given the material, size, and location of the statue. It should be noted that Theophanes claims that the statue was demolished "1360 years after it had been built". Thus, although the monument was apparently restored and re-erected in the reign of Hadrian, its original construction date was still highlighted in the 8th century and beyond. The inscription below the Colossus which provided the names of the original builders, as Constantine VII Porphyrogenetus notes, was well in keeping with Hadrian's proclivity to omit his own

\footnotetext{
50 Theophanes, Chronographia, 343, 7-10. Translated by C. A. Mango, R. Scott, and G. Greatrex. See also commentary in Conrad 1996.

${ }^{51}$ For a list of references, see Conrad 1996. For Rhodes in the early medieval period, see Roberts 2016 with bibliography; De Callatay 2006.

${ }^{52}$ Constantine VII Porphyrogenitus, De Administrando Imperio 20.7-10. Translated by R.J.H. Jenkins. Note that Anth. Pal. 6.171 preserves the supposed original inscription on the Colossus, which further enhances the notion that the inscription transmitted by Porphyrogenetus must be a later - probably Hadrianic addition. The original inscription supposedly read as follows: To you, Helios, yes to you the people of Dorian Rhodes raised this colossus high up to the heaven, after they had calmed the bronze wave of war, and crowned their country with spoils won from the enemy. Not only over the sea but also on land they set up the bright light of unfettered freedom.
} 
name from the buildings he restored. ${ }^{53}$ Indeed, the inscription cited above, which may have been part of the same inscription referenced by Malalas, vaguely recalls the type of wording chosen for the famous inscription in the Pantheon in Rome, ${ }^{54}$ which Hadrian also restored. In any case, it would have been unlikely that one of the original seven wonders of the ancient world would have gone unnoticed by Hadrian. Certainly, such a grand restoration would have brought increased interest in and revenue for Rhodes, an island whose fortunes were already favorable in the Roman period.

If Hadrian sailed from Asia to Athens "by way of the islands", as the Historia Augusta claims, which other islands might have been on his route? There is good reason to assume that he sojourned on the Cycladic island of Paros, about half-way on his journey from Rhodes to Athens. Paros' marble quarries were prized in antiquity, and these, along with other quarries in the Empire, were under the direct control of the reigning emperor. Hadrian often travelled with a coterie of architects, craftsmen, engineers, artists, and other professionals, ${ }^{55}$ so a stopover on Paros to inspect its famous marble quarries may have been necessary. Marble from the island was used frequently for portraits of the emperor and members of his family and court as well as for various building projects across the Empire, but this need not suggest that he was directly responsible for this choice in material. Hadrian may have also desired to visit the island for another reason.

Paros was the home of one of the most famous literary figures of Greek antiquity, the Archaic-period poet Archilochus (680-645 BCE), whom the islanders continued to honor long after his death. ${ }^{56}$ The Palatine Anthology preserves Hadrian's epigram for the poet's tomb: ${ }^{57}$

This is Archilochus' grave, whom to raging iambics

the Muse led, favoring the Maionian (i.e. Homer).

\footnotetext{
${ }^{53} \mathrm{HA}, \mathrm{Hadr}$., 9.9. He did not include his name on buildings he commissioned apart from that of the temple of Trajan in Rome.

${ }^{54}$ M. AGRIPPA.L.F.COS.TERTIUM.FECIT.

${ }^{55}$ Epit. de Caes., 150.

${ }^{56}$ Arist., Rh., 1398b. The cult of Archilochus was active on Paros until at least the 3rd century CE. See especially Clay 2004, 34-39; Hawkins 2014, 26.

${ }^{57}$ Anth. Pal., 7.674. Translated by W.R. Paton.
} 
As with his veneration and restoration of tombs of other famous Greeks, such as those of Epaminondas in Mantineia and Alcibiades in Phrygia, ${ }^{58}$ the veneration of Archilochus' tomb on Paros was highly symbolic: the emperor was not only displaying his knowledge of and fondness for the Hellenic past, which formed an important aspect of his imperial policy, but also imbuing the island with a renewed sense of local pride. Culture capital was valued highly in the 2nd century, and Paros, like many other insular and mainland communities, could boast of a glorious Greek past via its famous poet and sculptors. Thus, although there is no epigraphic evidence for Hadrian's presence on the island, it is unlikely that he composed the epigram elsewhere and sent it to Paros to be set up on Archilochus' tomb. It is evident that the emperor honored the tombs of other illustrious individuals in person, ${ }^{59}$ and, as the Historia Augusta informs us, "so fond was he of travel, that he wished to inform himself in person about all that he had read concerning all parts of the world". ${ }^{60}$

Since Hadrian stopped on Paros on his way from Rhodes to Athens, what other islands might he have visited on this trip from Asia to Achaea? Leaving aside some of the larger Aegean islands, the sea route would have taken him to other Cycladic islands. Although in decline for centuries, the sacred island of Delos, ${ }^{61}$ birthplace of Apollo and Artemis, would have been of interest to him as a site of panhellenic religious significance. Another possible candidate for a stopover on his way to Athens is the island of Syros, where a statue of him and an epigraphic document recording the islanders' gratitude for his benefactions have been discovered. ${ }^{62}$ However, such dedications are prevalent in both insular and mainland sites and do not necessarily confirm his direct presence in those locations. Indeed, if the prevalence of statues is an indication of an imperial visit, then the emperor would have certainly visited Crete since the island has produced more statues and statue bases of Hadrian than any other place in Greece apart from Attica. ${ }^{63}$ To date, no literary or epigraphic evidence confirms his presence on Crete, although it is difficult

\footnotetext{
${ }^{58}$ Tomb of Epaminondas: Paus. 8.11.8; tomb of Alcibiades: Ath. 13.574F; on the implications of Hadrian's restorations of older tombs in general, see Kouremenos forthcoming.

${ }^{59}$ On this subject, see Kouremenos forthcoming.

${ }^{60} \mathrm{HA}, \mathrm{Hadr}$., 17.8 .

${ }^{61}$ On Delos in the Roman period, see more recently Le Quéré 2018 with bibliography.

${ }^{62}$ For imperial visits as occasions for the erection of portrait statues, see especially Højte 2000. Although dated, Dürr 1881 references many inscriptions dedicated to Hadrian on the Greek islands, including two from Syros on p. 58.

${ }^{63}$ On statues of Hadrian from Crete, see Karanastasi 2012 and 2016 with bibliography; Gergel 2004; Birley 1997, 153 speculates that Hadrian visited Crete in 123 on his way to Greece from North Africa.
} 
to fathom that the largest Greek island with its many historic sites would have escaped an official visit on his numerous trips to the East. Other islands that almost certainly received a visit or visits from Hadrian include Aegina and Salamis, both closely connected to his favorite city. In any case, by Autumn of 124, Hadrian was back in Athens, where he conferred benefactions, revised the local laws, and perhaps served as eponymous archon for a second time. ${ }^{64}$ It was during this period that he was also initiated, like Augustus before him, into the Eleusinian Mysteries, although this may have been his second initiation. ${ }^{65}$

The Historia Augusta states that Hadrian was "initiated into the Eleusinian Mysteries in the manner of Heracles and Philip". ${ }^{66}$ The former was initiated into the Mysteries with Theseus as sponsor, ${ }^{67}$ but no other ancient source mentions Philip II of Macedon as an initiate. ${ }^{68}$ However, Philip and his wife Olympias were initiated into the Cabyrian Mysteries of Samothrace, ${ }^{69}$ so an interest in the Eleusinian Mysteries on the Macedonian king's part would not have been out of character. If Hadrian was indeed following in the footsteps of Heracles and Philip by being initiated into the Eleusinian Mysteries, could he also have been following in the footsteps of the latter by initiating himself into the Cabyrian Mysteries as well? Some confirmation for this is provided by Jerome, who notes that the emperor initiated himself in most of the mysteries of Hellas. ${ }^{70}$ Fragments of an epigraphic document with the names of Roman initiates suggest that the Sanctuary of the Great Gods and the island as a whole were in relative poverty in Hadrian's reign since no one assumed the financial burden of the eponymous magistracy. ${ }^{71}$ Wouldn't the islanders, knowing the emperor's religious and cultural predilections, appeal to him for financial assistance? Interestingly, an edict of Hadrian from Maroneia in Thrace, ${ }^{72}$ located on the mainland across from Samothrace, confirms his presence in that city and may date to his third official visit to Greece as emperor in

\footnotetext{
${ }^{64}$ Kapetanopoulos 1992-1998, 217-218; Kouremenos forthcoming.

${ }^{65}$ Hadrian was probably initiated for the first time before becoming emperor; see most recently Camia 2022 with bibliography.

${ }^{66} \mathrm{HA}, \mathrm{Hadr}$., 13.1.

${ }^{67}$ Plut., Thes., 30.5 .

${ }^{68}$ Oliver 1950 argues — unconvincingly — that Philip is an error for Philopappos; on Hadrian and Philip II, see Kouremenos forthcoming.

${ }^{69}$ Plut., Alex., 2.1. For commentary, see Cole 1984; Greenwalt 2009; Schockmel 2012.

${ }^{70}$ Jerome, On Illustrious Men, Vit. Quadratus.

${ }^{71}$ See most recently Dimitrova 2008, 186-187 with bibliography.

${ }^{72}$ See Jones 2011.
} 
131/132. It is, therefore, likely that a trip to nearby Samothrace may have also occurred at this time, even if there is no direct epigraphic evidence for his presence there.

Like Augustus before him, Hadrian also granted islands as gifts; he ceded at least three islands to his most favored Greek cities. In his zeal to benefit Athens, he gave the city, "much money, an annual dole of grain, and the whole of the island of Cephallenia". 73 The grant of the Ionian island implied that revenue from it would have been transferred to Athens. Similarly, he granted the island of Caudus, located south of Crete, to Sparta. ${ }^{74}$ And when the Spartan magnate G. Julius Eurycles Herculanus bequeathed Cythera to Hadrian after his death, the emperor gave it to Sparta. ${ }^{75}$ These island grants reveal that smaller insular communities could be exploited to benefit larger or favored cities on the mainland. How the Cephallenians, Caudians, and Cytherans felt about being subjugated to Athens and Sparta has not been recorded, but we should assume that most of the islanders were not content to lose their autonomy.

\section{Conclusion}

This brief overview of Hadrian's presence on the Greek islands reveals that insularity often played an important role in Roman imperial politics during his reign but also had earlier imperial precedents. In the Julio-Claudian period, Augustus and Tiberius chose to sojourn on Aegean islands in order to escape from and conduct political business away from Rome. The Greek islands were located far enough from the capital to allow these imperial personages some freedom to exercise their will and power away from the authority of the senate and the prying eyes of their families. At the same time, the Greek islands were accessible enough to allow them to receive visitors from other parts of the Roman Empire. The historical and cultural prestige of certain islands was not lost on the Julio-Claudians and some of their successors, but Hadrian took it a step further. While two of his Julio-Claudian predecessors sojourned on Greek islands for months or even years, as in the case of Tiberius, Hadrian paid short visits to them primarily for cultural and religious purposes as part of his wider policies of consolidation and Hellenocentrism. He did not single out specific islands due to their insularity or because of a desire to isolate

\footnotetext{
${ }^{73}$ Cass. Dio 69.16.2.

${ }^{74}$ Cartledge and Spawforth 2002, 99ff.

75 On Hadrian's bequeathing of islands to Athens and Sparta, see Birley 1997; Steinhauer and Paspalas 2006/2007 with bibliography. Cass. Dio, 54.7.2 notes that Augustus had also granted Cythera to Sparta as a favor to the latter.
} 
himself; islands simply formed part of his grander vision for the Greek world and were as linked to the Hellenic past as the sites on the mainland. As such, they were simply an extension of and a link with the mainland, and their proximity and connectivity to the Roman provinces in Greece and Asia allowed the imperial traveler and his entourage quick access to these lands, with islands serving as stepping-stones. It was not their insularity that appealed to Hadrian as much as their unique history and connection to the ancient Greek past. As such, his relationship to the Greek islands differed markedly from that of Augustus and Tiberius, who mainly used them to further their personal and political agendas in the Roman present rather than focusing on the islands' standing in the Roman world via their historical and religious past.

Article received in: 10/11/2021

Approved in: 23/12/2021 
Mare Nostrum, ano 2021, v. 12, n. 2

\section{BIBLIOGRAPHIC REFERENCES}

Ager, S. L. (1991). Rhodes: the rise and fall of a neutral diplomat. Historia: Zeitschrift für Alte Geschichte, (H. 1), 10-41.

Ashton, R. H. J. (2001). The coinage of Rhodes 408-190 BC. In A. Meadows and K. Shipton (Eds.) Money and its uses in the ancient Greek world. Oxford: Oxford University Press, 79-115.

Ashton, R. (1988). Rhodian coinage and the Colossus. Revue numismatique, 6(30), 7590.

Bellemore, J. (2007). Tiberius and Rhodes. Klio, 89(2), 417-453.

Birley, A. (1997). Hadrian: The Restless Emperor. London: Routledge.

Boatwright, M.T. (2000). Hadrian and the Cities of the Roman Empire. Princeton: Princeton University Press.

Bowersock, G. W. (1964). Augustus on Aegina. The Classical Quarterly, 14(1), 120-121.

Bowie, E. L. (2002). Hadrian and Greek poetry. In E.N. Ostenfeld (Ed.) Greek Romans and Roman Greeks: Studies in Cultural Interaction. Aarhus: Aarhus University Press, 172-197.

Bowie, E. L. (1997). Hadrian, Favorinus, and Plutarch. In J. Mossman (Ed.) Plutarch and his Intellectual World. London: The Classical Press of Wales, 1-15.

Bradford, A. (1986). The Date Hadrian was Eponymous Patronomos of Sparta. Horos 4, 71-74.

Braginton, M. V. (1944). Exile under the Roman emperors. The Classical Journal, 39(7), 391-407.

Brennan, T. C. (1998). The poets Julia Balbilla and Damo at the colossus of Memnon. The Classical World, 91(4), 215-234.

Camia, F. (2022). Hadrianos Olympios Panhellenios: Worshipping Hadrian in Roman Athens. In A. Kouremenos (Ed.). The Province of Achaea in the 2nd Century CE: The Past Present. London and New York: Routledge, 93-116.

Cartledge, P. and A.J.S Spawforth (2002). Hellenistic and Roman Sparta. A Tale of Two Cities. London and New York: Routledge.

Cole, S. G. (1984). Greek Initiates And Theoroi At Samothrace. In Theoi Megaloi: The Cult of the Great Gods at Samothrace. Leiden: Brill, 38-56.

Collart, P. (1932). Favorinus d'Arles. Bulletin de l'Association Guillaume Budé, 34(1), 23-31. 
Conrad, L. I. (1996). The Arabs and the Colossus. Journal of the Royal Asiatic Society, 6(2), $165-187$.

D’Ambrosi, D. T. (2020). Les Voyages d'Hadrien: Sur les traces de l'empereur nomade. Paris: Arkhê Editions.

De Callatay, G. (2006). The Colossus of Rhodes: Ancient Texts and Modern Representations. In C. Ligota and J.L. Quantin (Eds.), History of Scholarship: A Selection of Papers from the Seminar on the History of Scholarship Held Annually at the Warburg Institute. Oxford: Oxford University Press, 39-74.

D' Hautcourt, A. (1995). L'exil de Cassius Severus: hypothèse nouvelle. Latomus, 54 (Fasc. 2), 315-318.

Dimitrova, N. M. (2008). Theoroi and initiates in Samothrace: the epigraphical evidence (Vol. 37). Hesperia Supplement, 37. Princeton: American School of Classical Studies at Athens.

Dürr, J. (1881). Die Reisen des Kaisers Hadrian. Vienna: C. Gerold's Sohn.

Enos, R. L. (2004). The art of rhetoric at Rhodes: an eastern rival to the Athenian representation of Classical rhetoric. In C.S. Lipson and R.A. Binkley (Eds.) Rhetoric Before and Beyond the Greeks. Albany, 183-96.

Erskine, A. (1991). Rhodes and Augustus. Zeitschrift für Papyrologie und Epigraphik, 271-275.

Evans, S. H., A.C. Grayling, T. Holland, and L. Xinran. (2015). On forgotten free-speech heroes. Index on Censorship, 44(2), 87-90.

Francis, J. and A. Kouremenos (Eds.) (2016). Roman Crete: New Perspectives. Oxford: Oxbow.

Galimberti, A. (2010). Hadrian, Eleusis, and the beginning of Christian apologetics. In M. Rizzi (Ed.) Hadrian and the Christians. New York: Walter de Gruyter, 71-84.

Gergel, R. A. (2004). Agora S166 and related works: the iconography, typology, and interpretation of the Eastern Hadrianic breastplate type. Hesperia Supplements, 33, 371-409.

Gleason, M. W. (1994). Making Men: Sophists and Self-Representation in Ancient Rome. Princeton: Princeton University Press.

Greenwalt, W. S. (2009). Philip and Olympias on Samothrace. Macedonian Legacies: Papers on Macedonian Culture and History in Honor of Eugene N. Borza. Claremont, Calif, 79-106. 
Mare Nostrum, ano 2021, v. 12, n. 2

Grigoropoulos, D. (2015). Hadrian, Abai and the Memory of the Persian Wars. In D. Panagiotopoulos, I. Kaiser, and O. Kouka (Eds.) Ein Minoer im Exil. Festschrift für Wolf-Dietrich Niemeier. Bonn: Dr Rudolf Habelt Verlag GmbH, 75-98.

Gruen, E. S. (1975). Rome and Rhodes in the Second Century BC: A Historiographical Inquiry. The Classical Quarterly, 25(1), 58-81.

Halfmann, H. (1986). Itinera principum: Geschichte und Typologie der Kaiserreisen im Römischen Reich. Stuttgart: F. Steiner Verlag.

Haynes, D.L.A (1957). Philo of Byzantium and the Colossus of Rhodes. JHS 77, 311-12. Hawkins, T. (2014). Iambic Poetics in the Roman Empire. Cambridge: Cambridge University Press.

Højte, J. M. (2000). Imperial Visits as Occasion for the Erection of Portrait Statues?. Zeitschrift für Papyrologie und Epigraphik, 221-235.

Isager, J. (Ed.) (2001). Foundation and Destruction: Nikopolis and Northwestern Greece. Aarhus: Aarhus University Press.

Jones, C. P. (2011). An edict of Hadrian from Maroneia. Chiron, 41, 313-326.

Kennell, N. (2022). Memory and identity among the ephebes of 2nd-century Achaea. In A. Kouremenos (Ed.) The Province of Achaea in the 2nd Century CE: The Past Present. London and New York: Routledge, 13-34.

Kapetanopoulos, E. (1992-1998). The Reform of the Athenian Constitution under Hadrian. Horos 10-12, 215-237.

Karanastasi, P. (2016). Roman Imperial Sculpture from Crete: A Reappraisal. In J. Francis and A. Kouremenos (Eds.) Roman Crete: New Perspectives. Oxford: Oxbow, 101-118.

Karanastasi, P. (2012). Hadrian im Panzer: Kaiserstatuen zwischen Realpolitik und Philhellenismus. Jahrbuch des Deutschen Archäologischen Instituts, 127, 323-391.

Kebric, R. B. (2019). The Colossus of Rhodes: Its Height and Pedestal. Athens Journal of Humanities and Arts, 259-298.

Kirsten, E. (1987) The origins of the first inhabitants of Nikopolis. In E. Chrysos (Ed.) Nicopolis I: Proceedings of the First International Symposium on Nicopolis (23-29 September 1984). Preveza, 91-98.

Kouremenos, A. (forthcoming). The Roman Past of Greece. London and New York: Routledge.

Kouremenos, A. (Ed.) (2022). The Province of Achaea in the 2nd Century CE: The Past Present. London and New York: Routledge. 
Lagogianni-Georgakarakos, M. and E. Papi (2018). HADRIANVS-AAPIANOE: $O$

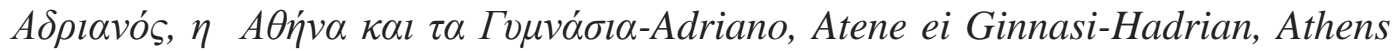
and the Gymnasia [exhibition catalogue]. SAIA: Scuola Archeologica di Atene.

Le Quéré, E. (2018). Was Delos Really Adelos? A Reappraisal of the Delian Solitude in Roman Imperial Times. In V. Di Napoli, F. Camia, V. Evangelidis, D. Grigoropoulos, D. Rogers, and S. Vlizos (Eds.) What's New in Roman Greece? Recent Work on the Greek Mainland and the Islands in the Roman Period. Athens: Meletemata 80, 111-121.

Levick, B. M. (1972). Tiberius' Retirement to Rhodes in 6 BC. Latomus, 31(Fasc. 3), 779813.

Magie, D. (1908). The Mission of Agrippa to the Orient in 23 BC. Classical Philology, 3(2), 145-152.

Maryon, H. (1956). The Colossus of Rhodes. The Journal of Hellenic Studies, 76, 68-86.

Morgan, G. (2006). 69 AD: the year of four emperors. Oxford: Oxford University Press.

Oliver, J. H. (1950). Hadrian's Precedent, the Alleged Initiation of Philip II. The American Journal of Philology, 71(3), 295-299.

Purcell, N. (1987). The Nicopolitan synoecism and Roman urban policy. In E. Chrysos (Ed.) Nicopolis I: Proceedings of the First International Symposium on Nicopolis (23-29 September 1984). Preveza, 71-90.

Roddaz, J. M. (2005). Culte impérial et fidélité dynastique: Agrippa et l'île de Lesbos. Studia historica. Historia antigua, (23), 401-412.

Rudich, V. (2006). Navigating the uncertain: Literature and censorship in the early Roman Empire. Arion: A Journal of Humanities and the Classics, 14(1), 7-28.

Rutledge, S. H. (2008). Tiberius' philhellenism. Classical World, 453-467.

Schmalz, G. C. (1996). Athens, Augustus, and the Settlement of 21 BC. Greek, Roman, and Byzantine Studies, 37(4), 381-398.

Schockmel, B. (2012). The Sanctuary of the Great Gods at Samothrace: Hellenistic Patronage and Politics. Art History Honors Projects. 6.

Seager, R. (1972). Tiberius. Berkeley: University of California Press.

Seebacher, C. (2020). Zwischen Augustus und Antinoos. Tradition und Innovation im Prinzipat Hadrians (Studies in Ancient Monarchies, Vol. 6.) Stuttgart: Steiner Verlag.

Spawforth, A. J. (2011). Greece and the Augustan cultural revolution. Cambridge: Cambridge University Press. 
Mare Nostrum, ano 2021, v. 12, n. 2

Steinhauer, G., and S.A. Paspalas (2006). The Euryklids And Kythera. Mediterranean Archaeology, 19/20, 199-206.

Swain, S., and K. van Bladel (2008). Seeing the Face, Seeing the Soul: Polemon's Physiognomy from Classical Antiquity to Medieval Islam. Aestimatio: Critical Reviews in the History of Science, 5, 225-233.

Swain, S. (1989). Favorinus and Hadrian. Zeitschrift Für Papyrologie Und Epigraphik, 79, 150-158.

Sweetman, R. J. (2016). Networks: exile and tourism in the Roman Cyclades . in J. F. D. Frakes M. Egri, and S. E. Alcock (Eds.) Beyond Boundaries: Connecting Visual Cultures in the Provinces of Ancient Rome. Los Angeles: Getty Publications, 4661.

Van Nijf, O. and Meijer, F. (1992). Trade, Transport and Society in the Ancient World. London: Routledge.

Weller, J. A. (1958). Tacitus and Tiberius' Rhodian Exile. Phoenix, 12(1), 31-35.

Yorke, V. W. (1896). Excavations at Abae and Hyampolis in Phocis. The Journal of Hellenic Studies, 16, 291-312.

Zoumbaki, S. (2018). Where East Meets West: Island Societies of the Ionian Sea Under Roman Rule. In A. Kouremenos (Ed.) Insularity and Identity in the Roman Mediterranean. Oxford: Oxbow, 77-106. 


\section{Insularidade E Política IMPERIAL: Adriano Nas IlHas Gregas}

Anna Kouremenos

\section{RESUMO}

Desde a sua conquista por Roma no século II AEC, os notáveis romanos eram uma presença constante na Grécia. Enquanto vários locais no continente serviram de campo de batalha para as guerras civis romanas durante o século I AEC (por exemplo, Pharsalos, Actium, Philippi), o início do período imperial foi caracterizado (muitas vezes por auto-imposição) pelo uso de várias ilhas gregas como lugares de exílio e/ou isolamento para notáveis como M. Vipsanius Agrippa (Lesbos) e Tiberius (Rodes). Outros romanos imperiais permaneceram nas ilhas do Mar Egeu por diferentes razões. Augusto passou um inverno em Samos após sua vitória em Actium, usando-a como base temporária de poder para o refinamento de seus planos imperiais, e ele a visitou e também a outras ilhas novamente como imperador. Enquanto os dois primeiros imperadores júlio-claudianos mantiveram estreitos contatos com o mundo grego, no século II EC Adriano levou esta conexão um passo adiante e promoveu o helenismo como uma parte importante de sua política imperial. Naturalmente, as ilhas gregas desempenharam um papel importante na política imperial durante seu reinado, mas apenas como componentes do mundo helênico mais amplo e não como entidades isoladas. Adriano visitou Rodes e Paros para restaurar e venerar monumentos helênicos mais antigos - o Colosso e o túmulo do poeta Arquíloco, respectivamente - e possivelmente a Samotrácia a fim de ser iniciado nos Mistérios dos Grandes Deuses. Ele também visitou outras ilhas na Grécia, mas seu itinerário exato de viagem só pode ser especulativo dadas nossas evidências literárias e epigráficas fragmentárias. Neste artigo, me concentro na presença de Adriano nas ilhas do Mar Egeu e discuto que durante seu reinado elas serviram principalmente como locais que permitiram a implementação de seus planos imperiais, em virtude de seu fácil acesso a partir das províncias da Grécia continental e da Ásia. Assim, ao promover certos aspectos da cultura helênica mais antiga em ilhas específicas, Adriano conferiu prestígio renovado a essas ilhas no Império Romano.

\section{PALAVRAS-CHAVE}

Grécia romana, Adriano, insularidade, imperialismo romano, ilhas egeias. 